\title{
Zoochemical Analyses and In vitro Antimicrobial Activity of Crude Methanolic Extract of Perna viridis
}

\author{
Joenilo E. Paduhilao II and Leni G. Yap-Dejeto, PhD \\ Department of Natural Sciences and Mathematics, Tacloban College, University of the Philippines Visayas, Tacloban City, Leyte, Philippines
}

\begin{abstract}
Introduction. The rise of antibiotic resistance and superbugs drives the search for new antibiotics today. Meanwhile, the green mussel Perna viridis is a cultivated and marketed staple bivalve in the Philippines due to its fast reproduction, high protein content, and tolerance to environmental variables. Although some studies have analyzed the antimicrobial activity of $P$. viridis, zoochemical analyses and further evaluation of its antimicrobial activity, such as determining the minimum inhibitory concentration (MIC), remains unexplored.
\end{abstract}

Objectives. The study evaluated the zoochemicals present in crude methanolic extract of $P$. viridis by qualitative screening and thin-layer chromatography analysis. It further evaluated the crude extract for its antimicrobial activity against common pathogenic bacteria and plant pathogenic fungi.

Materials and Methods. The zoochemicals in crude methanolic extract of $P$. viridis were screened using qualitative spotting methods and thin-layer chromatography (TLC). The antimicrobial activity of the extract was evaluated against the bacteria Escherichia coli, Pseudomonas aeruginosa, Staphylococcus aureus, and Bacillus subtilis, and the fungi Colletotrichum capsici, Lasiodiplodia theobromae, and Rhizopus sp. using disk diffusion assay and two-fold microdilution.

Results. Qualitative screening and thin-layer chromatography analysis of the crude extract revealed detectable amounts of alkaloids, saponins, terpenoids, sterols, and polyphenols. All of the tested bacteria were susceptible to the extract with P. aeruginosa $(19.00 \pm 0.82 \mathrm{~mm})$ and $S$. aureus $(19.33 \pm 0.47 \mathrm{~mm})$ as the most inhibited with MICs of $2.60 \pm 0.63$ and $3.65 \pm 1.69 \mathrm{mg} / \mathrm{mL}$, respectively. However, for the three fungi tested, only the growth of the fungus L. theobromae $(7.33 \pm 0.94 \mathrm{~mm})$ was inhibited with a MIC of $33.33 \pm 11.79 \mathrm{mg} / \mathrm{mL}$.

Conclusion. It can be inferred that the zoochemicals detected in the crude extract of $P$. viridis contributed to its antimicrobial activity.

Key Words: Antibacterial agent, Antifungal agent, Green mussel, Plant pathogenic fungi, Secondary metabolites

\section{INTRODUCTION}

Presented in the $13^{\text {th }}$ Philippine National Health Research System (PNHRS) week celebration, $2^{\text {nd }}$ Place in the Oral Research Competition (Student Category) on August 13-16, 2019 in Limketkai Hotel, Cagayan de Oro, Misamis Oriental, Philippines.

Corresponding author: Joenilo E. Paduhilao II Department of Natural Sciences and Mathematics Tacloban College

University of the Philippines Visayas

Tacloban City, Leyte, Philippines

Email: jepaduhilao@alum.up.edu.ph
The ocean is home to organisms that produce bioactive metabolites. The biodiversity that the ocean houses may lead to the ecosystem becoming a renewable repository of solutions for global issues such as the threat of antibiotic resistance. With the current trend on the evolution of resistance of pathogens to existing antibiotics, marine faunae are sought for their biomolecules to counter the demand for novel compounds. ${ }^{1}$ Currently, there is an increased interest in the screening of antimicrobial compounds isolated from molluscan species. ${ }^{2}$ The bivalve Perna viridis gained attention in the research field in the Philippines due to its varying economic and trade dynamics despite the industrial biofouling issue. ${ }^{3}$ Some studies have investigated the anti- 
inflammatory, antioxidant, antibacterial, and antifungal bioactivities of $P$. viridis. ${ }^{4-6}$ The antimicrobial compounds present in the methanol and ethanol extracts of $P$. viridis was identified in another study using high-performance thin-layer chromatography (HPLC). Based on the results, the fractionated components were protein by nature instead of possessing properties that were related to secondary metabolites. ${ }^{7}$ From the mentioned bioactivities, the majority of the investigations inferred proteins to be responsible for their bioactive potential. However, only a few studies have suggested secondary metabolites as the ones responsible for its bioactivity.

Secondary metabolite is a broad classification of biomolecules under the umbrella term zoochemicals found in fauna. ${ }^{8}$ With the current interest in extracting valuable metabolites, such as terpenoids and sterols, in marine organisms, $P$. viridis may serve as a prolific source of secondary metabolites mainly active for defense. ${ }^{9}$ Hence, a baseline study to further identify bioactive compounds, not only proteins in $P$. viridis, is needed.

Furthermore, studies conducted on the antimicrobial bioactivity of $P$. viridis extracts poorly studied the Minimum Inhibitory Concentration (MIC) against the tested organisms even if the zones of inhibition observed were inferred to as susceptible compared to the standards. Bridging its activity on both fungal and bacterial test organisms, this study serves as baseline on a wide range of spectrum for the methanolic extract of $P$. viridis exhibiting antimicrobial capacity using secondary metabolites. It also determined the MIC on susceptible test organisms. This also pioneers the testing of a zoochemical-based extract on plant pathogens. To our knowledge, there are no known studies on the antifungal activity of animal extracts against the plant pathogen fungi Colletotrichum capsici and Lasiodiplodia theobromae.

\section{MATERIALS AND METHODS}

\section{Mussel Methanolic Extraction}

Perna viridis samples were bought from Jiabong, Samar. These were sent to the Bureau of Fisheries and Aquatic Resources for identification and certification. The samples were freed of adhering debris using tap water and followed with distilled water. One hundred fifty-two (152) grams Perna viridis whole mussel tissue was separated from the shells. These were homogenized with a blender and macerated following a 1:2 and 1:1 homogenate weight to methanol volume ratios. Initially, the homogenates were macerated (1:2) with $304 \mathrm{~mL}$ Methanol $(\mathrm{MeOH})$ and incubated for 48 hours at $4^{\circ} \mathrm{C}$. The mixture was centrifuged at 6000 rpm for 20 minutes and the supernatant was collected and vacuum-filtered (Nalgene filtration bottle) using Whatman paper no.1. The resulting residue was extracted using 152 $\mathrm{mL} \mathrm{MeOH} \mathrm{(1:1)} \mathrm{following} \mathrm{the} \mathrm{same} \mathrm{1:2} \mathrm{weight-to-MeOH}$ volume ratio. The supernatant were pooled and concentrated using a rotary evaporator at $35-55^{\circ} \mathrm{C}$ under reduced pressure. ${ }^{5}$

\section{Zoochemical Screening}

\section{Test for Alkaloids}

Ten (10) $\mathrm{mg}$ of the sample was obtained and $2 \mathrm{~mL}$ of $2 \% \mathrm{HCl}$ was added. The sample was boiled in a hot water bath and the mixture was filtered. Two drops of $1 \%$ picric acid solution was added to $1 \mathrm{~mL}$ of the filtrate. The formation of a yellow precipitate indicated the presence of alkaloid. ${ }^{10}$

\section{Test for Flavonoids}

Ten (10) $\mathrm{mg}$ of the crude sample was mixed with 5 $\mathrm{mL}$ ethyl acetate. The mixture was heated for 3 minutes and then filtered. The filtrate $(4 \mathrm{~mL})$ was mixed with $1 \mathrm{~mL}$ diluted ammonia solution. The formation of an intense yellow coloration indicated the presence of flavonoids. ${ }^{11}$

\section{Test for Polyphenols}

Two (2) drops of ferric chloride (5\%) was added to the $10 \mathrm{mg}$ sample extract dissolved in $2 \mathrm{~mL}$ distilled water. The appearance of brown precipitate confirmed the presence of polyphenols. ${ }^{12}$

\section{Test for Saponins}

Ten (10) mg of the crude extract was obtained and added to $5 \mathrm{~mL}$ distilled water. The mixture was shaken and boiled. The appearance of frothing which was stable for 15- $30 \mathrm{~min}$ or longer confirmed the presence of saponins. ${ }^{13}$

\section{Test for Sterols - Liebermann-Burchard Test}

One (1) $\mathrm{mL}$ glacial acetic acid and $1 \mathrm{~mL}$ chloroform solution was prepared and cooled to $0^{\circ} \mathrm{C}$. A drop of concentrated sulfuric acid was added. Five (5) $\mathrm{mL}$ of the aqueous suspension sample was then added. The blue, green, red, or orange colors that changed with time confirmed the presence of sterols. ${ }^{13}$

\section{Test for Terpenoids - Salkowski Reaction}

One to two (1-2) $\mathrm{mg}$ of the sample was dissolved in 1 $\mathrm{mL}$ chloroform and $1 \mathrm{~mL}$ concentrated sulfuric acid was added. The formation of two phases with a red or yellow coloration confirmed the presence of terpenoids and sterols. ${ }^{14}$

\section{Test for Cardiac glycosides - Keller-Kiliani Test}

Ten (10) mg sample was mixed with $1 \mathrm{~mL}$ of glacial acetic acid. Then, two drops of $5 \%$ Ferric chloride followed by two drops of concentrated sulfuric acid was added. A greenblue coloration indicated the presence of cardiac glycosides. ${ }^{15}$

\section{Thin-Layer Chromatography Profiling}

Thin-layer chromatography was used to further evaluate the methanolic extract of $P$. viridis whole mussel tissues. TLC plates precoated with silica gel were cut into $4 \times 10 \mathrm{~cm}$ plates using a common household cutter. The plates were marked using a pencil and were loaded with $2000 \mathrm{ppm}$ of the extract $1 \mathrm{~cm}$ from the bottom. The TLC plates were 
developed in a $400 \mathrm{~mL}$ beaker with $10 \mathrm{~mL}$ of the solvent systems, Chloroform: Methanol: Water $(6.5: 2.5: 1)^{16}$, Chloroform: Methanol: Glacial Acetic Acid (83:17:10) ${ }^{17}$, Methanol: Dichloromethane: chloroform (30: 35: 35) ${ }^{4}$, Ethyl acetate: Methanol: Water (100: 13.5: 10) ${ }^{18}$, and Toluene: Chloroform: Acetone (5:3.1:4.3) ${ }^{19}$. The plates were developed using one-dimensional ascending method then viewed under UV light at $366 \mathrm{~nm}$.

The solvent system which developed the best chromatogram in terms of resolution and number of spots was further used for the derivatization of spots using the detection reagents Dragendorff's and Liebermann-Burchard. Separate chromatograms were developed for each derivatization reagent. In the case of Liebermann-Burchard Reagent, the chromatogram was heated at $100^{\circ} \mathrm{C}$ after spraying to develop the spots. ${ }^{20}$ The $\mathrm{Rf}$ values were measured using a ruler and the plates were photographed and analyzed using Image $1.51 \mathrm{j} 8$ in order to estimate the intensity and to measure the $\mathrm{Rf}$ value of each spot.

\section{Pathogen Procurement}

The bacterial cultures of Escherichia coli (ATCC 25922), Bacillus subtilis (ATCC 23857), Pseudomonas aeruginosa (ATCC 27853), and Staphylococcus aureus (ATCC 25923) were obtained from the Department of Science and Technology VIII, Leyte, Philippines. All bacterial cultures were stored in Nutrient agar (NA) slants at $4^{\circ} \mathrm{C}$.

Plant pathogenic fungi Lasiodiplodia theobromae, Colletotrichum capsici, and Rbizopus sp. were obtained from the Plant Disease Diagnostic Laboratory, Visayas State University, Philippines. The fungal cultures were recently isolated from infected plants and crops, as noted by the Research Specialist. All fungal cultures were maintained in Potato Dextrose Agar (PDA) slants at $4^{\circ} \mathrm{C}$. The microbial pathogens were stored and handled in a research laboratory with Biosafety level 2 (BSL-2). Upon execution of the microbiological aspect of the study, the antimicrobial testing was performed in a culture room with accessible UVradiation for room decontamination before the execution of experiments in the biosafety cabinet.

\section{Antimicrobial Activity Assay}

The Disk diffusion method was used to perform the antibacterial assay and the antifungal assay. ${ }^{21,22}$ The $100 \mathrm{mg} /$ $\mathrm{mL}$ crude methanolic extract was prepared by dissolving 200 $\mathrm{mg}$ of the extract in $2 \mathrm{~mL}$ sterile distilled water. The extract was stored in a sterile vial at $4^{\circ} \mathrm{C}$ until the antimicrobial assays were performed. A $0.5 \mathrm{McF}$ arland standard solution was also prepared before culture inoculations as turbidity standard for the culture suspensions. Briefly, $0.05 \mathrm{~mL}$ of $1.175 \%$ Barium chloride dihydrate $\left(\mathrm{BaCl} \cdot 2 \mathrm{H}_{2} 0\right)$ was mixed with $9.95 \mathrm{~mL}$ of $1 \%$ sulfuric acid $\left(\mathrm{H}_{2} \mathrm{SO}_{4}\right)$. For standardization, the prepared solution was adjusted to an absorbance reading range of 0.08 to 0.1 at $625 \mathrm{~nm}$ using a spectrophotometer. ${ }^{23,24}$
Before bacterial and fungal broth suspension preparation, all bacteria were subcultured in NA slants and incubated at $35^{\circ} \mathrm{C}$ for $18-24$ hours. Meanwhile, all fungi were maintained and subcultured in Potato Dextrose Agar (PDA) slants and incubated at $35^{\circ} \mathrm{C}$ for five days.

The bacteria were inoculated in a Luria Bertani Broth ( $\mathrm{pH}$ 6-7.5) and incubated at $35^{\circ} \mathrm{C}$ for at least $18-24$ hours to prepare a bacterial suspension. The bacterial suspension was compared to a $0.5 \mathrm{McFarland}$ solution and was adjusted accordingly. If the opacity does not coincide with the 0.5 McFarland standard, the opacity was reduced by adding sterile broth or increased by adding more bacterial inoculum. The swab method was then used to inoculate the bacteria to a Mueller-Hinton Agar. The inoculum was dried at room temperature for 10-15 min to ensure that excess moisture was absorbed and a confluent lawn of bacteria was produced.

In the fungal test organisms, the fungal suspensions were prepared by flooding the previously incubated culture with a $4 \mathrm{~mL} 0.9 \%$ Sterile Saline solution. The cultures were gently swabbed to dislodge the spores or conidia from the mycelial mat. The resulting suspension was allowed to settle for 5 minutes at room temperature and then transferred to sterile screw-capped test tubes. The suspensions were then standardized to $1 \times 10^{6}$ spores $/ \mathrm{mL}$ using a hemocytometer. The swab method was employed to inoculate the $200 \mu \mathrm{L}$ fungal suspension to the Potato Dextrose Agar. ${ }^{23}$

Three types of disks were separately prepared by impregnating $6 \mathrm{~mm}$ sterile Whatman no. 1 filter paper disks with sterile water as negative control, streptomycin as positive control for bacteria and fluconazole for fungi, and the crude $\mathrm{MeOH}$ extract.

For the crude extract, a $100 \mathrm{mg} / \mathrm{mL}$ concentration was prepared from storage and $50 \mu \mathrm{L}$ was added to the disks. Sterile water $(50 \mu \mathrm{L})$ was added as negative control and $50 \mu \mathrm{L}$ streptomycin or fluconazole $(10 \mathrm{mg} / \mathrm{mL})$ was eluted as positive control. After an hour of drying, the disks were placed on the surface of the agar and incubated at $35^{\circ} \mathrm{C}$ for $24 \mathrm{~h}$ (bacteria) or 3-5 days (fungi) in an inverted position. The three disks were placed equidistantly. The set-ups were performed in triplicates. Zone of inhibition (ZOI) was measured using a ruler. ${ }^{23,24}$

\section{Minimum Inhibitory Concentration Determination}

The Minimum Inhibitory Concentration (MIC) was determined for the crude extract which showed the highest antibacterial activity against the microorganisms tested as suggested by the National Committee for Clinical Laboratory Standards. ${ }^{24}$ The two-fold microdilution method was used to determine the MIC of the crude extract. The stock solutions of the crude extract were prepared by dissolving in distilled water $(100 \mathrm{mg} / \mathrm{mL})$. The crude extract was then tested at a concentration ranging from $100 \mathrm{mg} / \mathrm{mL}$ to $0.78 \mathrm{mg} / \mathrm{mL} .{ }^{24}$ All bacterial suspensions were prepared, and the turbidity was compared to the $0.5 \mathrm{McF}$ arland standard to signify $10^{5} \mathrm{CFU} / \mathrm{mL}$. 
On the other hand, the prepared standardized fungal suspensions at $1 \times 10^{6}$ spores $/ \mathrm{mL}$ were used. A $50 \mu \mathrm{L}$ bacterial/fungal suspension was inoculated to the medium and extract dilution and was incubated at $35^{\circ} \mathrm{C}$ for $18-20$ $\mathrm{h}$ (bacteria) or 3-5 days (fungi). The lowest concentration which displayed inhibition of bacterial growth was recorded as the MIC.

\section{Biological samples disposal}

After the execution of the microbiological assays, glasswares containing bacterial and fungal cultures were all autoclaved at $121^{\circ} \mathrm{C}$ and 15 psi (1.02 atm). Similarly, the same decontamination and sterilization procedure was followed for all of the glasswares used. Waste and used materials were disposed of properly in waste bags intended for biological samples provided by the General Laboratory of the University of the Philippines Visayas Tacloban College, Philippines.

\section{Data Analysis}

All tests were carried out in three replications and the data obtained were presented as mean \pm standard deviation.

\section{RESULTS}

\section{Zoochemical classes of Perna viridis}

The methanolic extract of the bivalve contained detectable levels of zoochemicals such as saponins, sterols, alkaloids, polyphenols, and terpenoids (Table 1).

\section{Thin-Layer Chromatography Profile}

Semi-quantification by TLC analysis yielded $R f$ values of zoochemicals present in the extract. Retention factor (Rf) value refers to the ratio of the distance moved by the compound and the distance moved by the solvent. The crude extract has various zoochemicals (Table 2). Development of the crude extract in all of the solvent systems except Chloroform: Methanol: Water (6.5:2.5:1) gave only one spot as viewed under UV light at $366 \mathrm{~nm}$. The development of the chromatogram at the solvent system Chloroform: Methanol: Water (6.5:2.5:1) gave four spots with $\mathrm{Rf}$ values of $0.87,0.82,0.77$, and 0.63 . Among the spots, the spot with an $\mathrm{Rf}$ value of 0.87 was the most intense with a percentage of $33.90 \%$. On the other hand, the spot with an Rf value of 0.63 gave off the least intense color under UV light with an intensity percentage of $19.30 \%$. Nevertheless, out of all the solvent systems, the latter gave the highest number of spots; hence, it was used to develop a chromatogram to be sprayed further by derivatization reagents.

The chromatograms developed at the solvent system Chloroform: Methanol: Water (6.5:2.5:1) were sprayed with Dragendorff's reagent and Liebermann-Burchard reagent separately to identify the classes of zoochemicals present in the sample extract. Dragendorff's reagent and LiebermannBurchard reagent gave colored spots that can be viewed

under UV light at $366 \mathrm{~nm}$ (Table 3). Two red spots were generated using Dragendorff's reagent with $\mathrm{Rf}$ values of 0.92 (Alkaloid 1) and 0.85 (Alkaloid 2). The red coloration indicated that the compounds present after spraying were alkaloids. The $\mathrm{Rf}$ values of the spots were also relatively high which signified that the separated compounds have medium polarity or were slightly polar. Results also showed that the spots generated after spraying with Dragendorff's reagent did not match any of the $\mathrm{Rf}$ values generated in the different solvent systems. This implied that the spots generated were separate or distinct from the spots generated from the different solvent systems.

Two spots were generated after derivatization with Liebermann-Burchard Reagent (Table 3). The spots were differently colored where the spot with an $\mathrm{Rf}$ value of 0.93 was colored gray and the spot with an $\mathrm{Rf}$ value of 0.40 was blue. The gray coloration indicated that the spot was

Table 1. Qualitative zoochemical screening of the crude methanolic extract of $P$. viridis

Zoochemical

Saponins

Polyphenols

Flavonoids

Alkaloids

Sterols

Terpenoids

Cardiac glycosides

Note: "+" indicates undetectable amount

Table 2. Rf values and intensity percentages of the spots generated in different solvent systems from the ThinLayer Chromatography (Silica gel) analysis

\begin{tabular}{|c|c|c|c|}
\hline Solvent System & $\begin{array}{l}\text { No. of } \\
\text { Spots }\end{array}$ & $\begin{array}{c}\text { Rf } \\
\text { Values }\end{array}$ & $\begin{array}{l}\text { Intensity } \\
\text { (\%) }\end{array}$ \\
\hline $\begin{array}{l}\text { Chloroform: Methanol: Water } \\
(6.5: 2.5: 1)\end{array}$ & 4 & $\begin{array}{l}0.87 \\
0.82 \\
0.77 \\
0.63\end{array}$ & $\begin{array}{l}33.90 \\
21.77 \\
25.03 \\
19.30\end{array}$ \\
\hline $\begin{array}{l}\text { Chloroform: Methanol: } \\
\text { Glacial Acetic acid (83:17:10) }\end{array}$ & 1 & 0.94 & - \\
\hline $\begin{array}{l}\text { Methanol: Dichloromethane: } \\
\text { Chloroform (30:35:35) }\end{array}$ & 1 & 0.96 & - \\
\hline $\begin{array}{l}\text { Ethyl acetate: Methanol: Water } \\
(100: 13.5: 10)\end{array}$ & 1 & 0.96 & - \\
\hline $\begin{array}{l}\text { Toluene: Chloroform: Acetone } \\
(5: 3.1: 4.3)\end{array}$ & 1 & 0.97 & - \\
\hline
\end{tabular}

Table 3. Colors, Rf Values, and Intensity Percentages of the spots generated in Chloroform: Methanol: Water (6.5:2.5:1) after derivatization with spraying reagents

\begin{tabular}{|c|c|c|c|c|c|}
\hline $\begin{array}{c}\text { Derivatization } \\
\text { Reagent }\end{array}$ & $\begin{array}{l}\text { No. of } \\
\text { spots }\end{array}$ & $\begin{array}{c}\text { Color of } \\
\text { spots }\end{array}$ & $\begin{array}{c}\text { Rf } \\
\text { Values }\end{array}$ & $\begin{array}{l}\text { Intensity } \\
\text { (\%) }\end{array}$ & $\begin{array}{l}\text { Compound } \\
\text { Class }\end{array}$ \\
\hline \multirow{2}{*}{$\begin{array}{l}\text { Dragendorff's } \\
\text { Reagent }\end{array}$} & \multirow{2}{*}{2} & \multirow{2}{*}{ Red } & 0.92 & 3.36 & Alkaloid 1 \\
\hline & & & 0.85 & 42.59 & Alkaloid 2 \\
\hline \multirow{2}{*}{$\begin{array}{l}\text { Liebermann- } \\
\text { Burchard Reagent }\end{array}$} & & Gray & 0.93 & 44.54 & Terpenoid 1 \\
\hline & & Blue & 0.40 & 9.51 & Saponin 1 \\
\hline
\end{tabular}




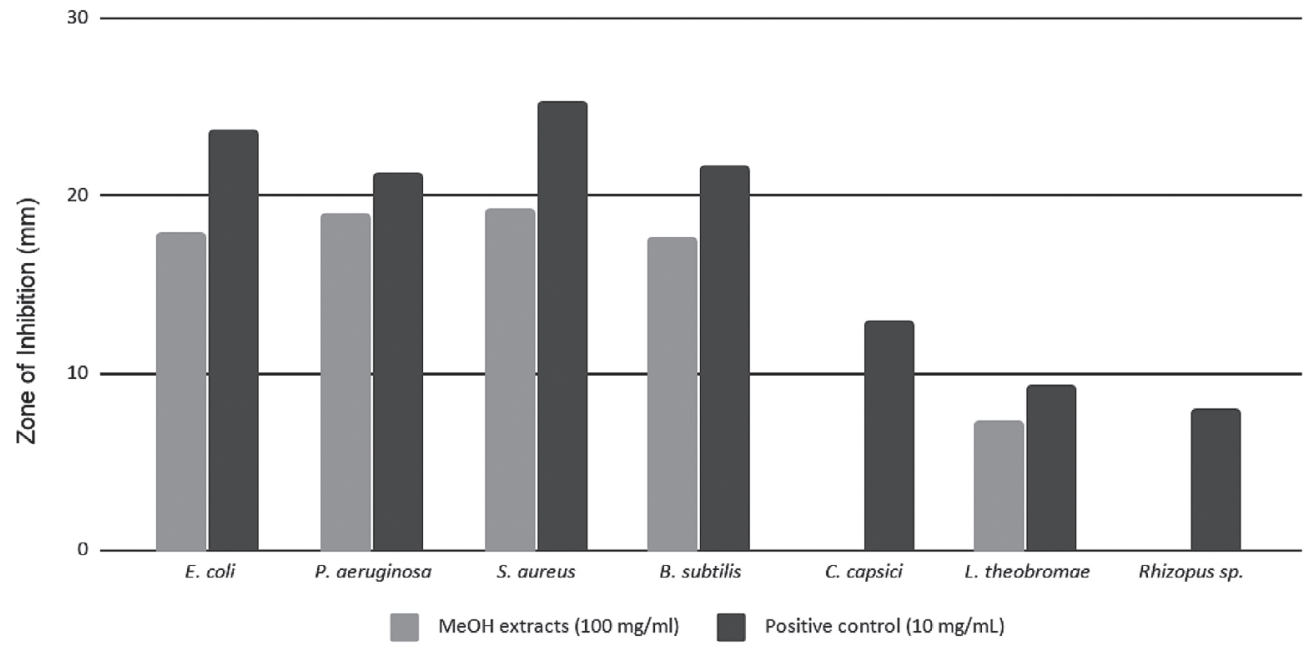

Figure 1. Antimicrobial activity of the crude methanolic extract of $P$. viridis (disk diameter is $6 \mathrm{~mm}$ ).

classified as terpenoid while the blue coloration indicated the compound as saponin (Wagner and Bladt 2001). The Rf values did not match the $\mathrm{Rf}$ values in the different solvent systems. Even more, a spot with an Rf value of 0.40 was generated which implied that it was the most polar among the other compounds present in the extract. Among the spots, Alkaloid 2 and Terpenoid 1 gave the most intense spots compared to the other two spots with an intensity percentage of $42.59 \%$ and $44.54 \%$, respectively. Hence, Alkaloid 2 and Terpenoid 1 comprised the majority of compounds separated by the solvent system.

\section{Antimicrobial Activity}

In this study, the antimicrobial activity of the crude methanolic extract at $100 \mathrm{mg} / \mathrm{mL}$ of $P$. viridis was screened using the disk diffusion assay. The study reported that all of the test bacteria were susceptible to the crude methanolic extract as compared to the standards published by the Clinical and Laboratory Standards Institute on antimicrobial susceptibility testing ${ }^{25}$ (Figure 1 ). Moreover, the results also revealed that the growth of $P$. aeruginosa and $S$. aureus were highly inhibited with mean zones of inhibition at $19.00 \pm 0.82 \mathrm{~mm}$ and $19.33 \pm 0.47 \mathrm{~mm}$, respectively. Meanwhile, the bacteria $E$. coli and B. subtilis were the least inhibited with a mean zone of inhibition of $18.00 \pm 1.25 \mathrm{~mm}$ and $17.67 \pm 0.94 \mathrm{~mm}$, respectively. In the case of fungi, only $L$. theobromae was inhibited by the crude extract with $7.33 \pm 0.94 \mathrm{~mm}$ of the zone of inhibition but interpreted as resistant based on the standards published by CLSI on non-dermatophyte fungi. ${ }^{26}$ The extract had no antifungal activity against the rest of the test fungi, Rhizopus sp. and C. capsici.

\section{Minimum Inhibitory Concentration}

The MIC assay using broth microdilution was performed on the bacteria and fungi that were inhibited by the extract, which included $E$. coli, $P$. aeruginosa, $S$.
Table 4. Minimum Inhibitory Concentration (MIC) of the crude methanolic extract of $P$. viridis against susceptible bacteria and fungus

$\begin{array}{cc}\text { Test Organism } & \mathrm{MIC}(\mathrm{mg} / \mathrm{mL}) \\ \text { E. coli } & 8.33 \pm 2.55 \\ \text { S. aureus } & 2.60 \pm 0.63 \\ \text { P. aeruginosa } & 3.65 \pm 1.69 \\ \text { B. subtilis } & 10.42 \pm 2.55 \\ \text { L. theobromae } & 33.33 \pm 11.79\end{array}$

aureus, B. subtilis, and L. theobromae (Table 4). However, standard MICs by CLSI suggested that the observed values in this study were still classified as resistant. ${ }^{25}$ Nevertheless, the extract was able to inhibit bacterial growth in various concentrations. The least MIC recorded was on $S$. aureus with a concentration of $2.60 \pm 0.63 \mathrm{mg} / \mathrm{mL}$.

Meanwhile, among the bacteria, the most excellent MIC recorded was against $B$. subtilis with a MIC of $10.42 \pm 2.55 \mathrm{mg} /$ $\mathrm{mL}$. For the sole fungi, the recorded MIC was $33.33 \pm 11.79$ $\mathrm{mg} / \mathrm{mL}$. Due to the unavailability of data for L. theobromae, no standard reference range could be compared in terms of MIC. However, CLSI suggests that any MIC value less than $64 \mu \mathrm{g} / \mathrm{mL}$ in comparison to fluconazole as the positive control is inferred to as resistant. ${ }^{26}$

\section{DISCUSSION}

The results of this study agreed with Sreejamole and Radhakrishnan that alkaloids, saponins, sterols, and polyphenols are present at detectable amounts in the crude methanolic extract of $P$. viridis whole mussel tissue. ${ }^{4}$ This study, however, revealed that terpenoids were also present in the methanolic extract of $P$. viridis.

Terpenoids have also been isolated in bivalve clams. Terpenoids, such as isopimarane norditerpenoids, act as precursors for the synthesis of sterols and steroids in bivalves. Since bivalves are filter and detritus feeders, 
algae and plankton are also sources of a wide variety of zoochemicals found in their system which include terpenoids and alkaloids. ${ }^{27,28}$

Sterols, such as cholesterol, are dominant in the class Bivalvia partly because of their antibacterial and protective role in spawns during their reproductive cycles. ${ }^{29}$ Polyphenols and saponins are present at detectable amounts in the crude methanolic extract of $P$. viridis. Novel polyphenols and saponins, however, are seldom isolated from bivalves. ${ }^{30}$ The occurrence of polyphenols and saponins in the extract of $P$. viridis using methanol as solvent have been studied and published. ${ }^{4,31}$ Gallic acid is a possible identifier of the polyphenol compound because they are commonly isolated from mytilids as part of their endogenous defense system. ${ }^{32}$ Meanwhile, further identification of the saponin compound present in this study is needed as there are no published reports of the occurrence of novel saponins from P. viridis. ${ }^{33,34}$ Possibly, the saponins may have originated from the plankton diet of $P$. viridis such as the diatoms Coscinodiscus spp. and Phaeodactylum spp. ${ }^{35}$

In this study, the solvent system chloroform-methanolwater gave the best results, which could mean that the compounds separated well in slightly polar solvents. This result was expected because the solvent used in the study was 95\% Methanol, a polar solvent. Alkaloid 2 and Terpenoid 1 gave the most intense spots compared to the other two spots providing an insight that the dominant compounds present in the extract originated from the $\operatorname{diet}$ of $P$. viridis, particularly planktonic microorganisms. ${ }^{28}$ Marine microalgae such as the genera Chlorella, Skeletonema, Dunaliella, Tetraselmis, and Isochrysis produce a considerable amount of phytochemicals such as alkaloids and terpenoids which could have been pooled in the tissues of bivalves because of their diet. ${ }^{36-38}$

In previous studies, $P$. viridis has been screened for its antibacterial activity against E. coli, Klebsiella pneumonia, Vibrio parahaemolyticus, Vibrio cholerae and many other bacteria. ${ }^{5}$ The literature suggests that the antibacterial activity of $P$. viridis was attributed to zoochemicals namely proteins, peptides, free amino acids, and lipids present in the crude methanolic extract. Literature also suggested that the screened molecules are polar by nature because methanol was used as the solvent. ${ }^{5,39}$ Nevertheless, the results agreed with the study conducted by Shanmugam et al. that the crude methanolic extract of $P$. viridis has higher growth inhibition against Pseudomonas sp. $(13.2 \mathrm{~mm})$ and $S$. aureus $(13.23 \mathrm{~mm})$ as compared to E. coli $(5.26 \mathrm{~mm})$ and B. subtilis $(5.06 \mathrm{~mm})$ at a dose of $2 \mathrm{mg} / \mathrm{mL} .{ }^{5}$ Also, the results agreed with the study conducted by Madhu et al. that the extract has a growth inhibitory effect against $E$. coli $(10 \mathrm{~mm})$ at a dose of $100 \mu \mathrm{g} / \mathrm{mL} .{ }^{39}$ In these studies, the authors implied that the antimicrobial activity of the methanolic crude extract may have been derived from the zoochemicals present such as antimicrobial peptides and narrowly, secondary metabolites such as alkaloidal compounds. ${ }^{40,41}$
The fungal species in this study have efflux pumps in their cell membrane which can decrease the concentration of the antifungal agent which led to the antifungal resistance. ${ }^{42}$ Both Rhizopus sp. and $C$. capsici have been reported to be characterized by ATP-driven efflux pumps. ${ }^{43,44}$ This provided an insight into the resistance of these fungi against the crude methanolic extract. Because L. theobromae was inhibited in terms of growth, a possible mechanism of antifungal activity of the candidate terpenoid and alkaloid in the extract would be the inhibition of germ tube formation and the inhibition of membrane-localized enzyme modifications, respectively. ${ }^{45-47}$ The antibacterial activity of the alkaloids and terpenoids present would possibly have mechanisms involving inhibition of the synthesis of ergosterol, the formation of aqueous pores, and inhibition of macromolecules. ${ }^{48,49}$ Particularly, candidate terpenoids may exhibit antibacterial activity by cytoplasmic degradation and cell membrane damage by promoting $\mathrm{K}^{+}$ ion leakage..$^{48}$ Consequently, candidate alkaloids can exhibit antimicrobial activities by inhibiting biofilm formation and enzyme modification such as membrane transporters. ${ }^{49}$ To date, most reports published on the antifungal activity of the extract against $L$. theobromae and C. capsici are of plant origin. No reports have been published on the screening of the antifungal activity of animal extracts against $L$. theobromae and C. capsici. Publications for zoochemicals screened against plant pathogens are limited, hence, little is known on their mechanism against the plant pathogenic fungi.

Meanwhile, the MICs reported in this study were comparable to the MICs reported in other literature, with the extract in this study inhibiting the growth of $S$. aureus at a lower concentration $(2.60 \mathrm{mg} / \mathrm{mL})$ compared to the study of Borquaye et al. which was at $5 \mathrm{mg} / \mathrm{mL} .^{50}$ Likewise, it was hypothesized that the compounds responsible for the inhibition of growth of the test bacteria were zoochemicals which were present in the tissues of the mollusks Littorina littorea and Galatea paradoxa..$^{50}$

For the fungus inhibited in this study, the MIC against L. theobromae $(33.33 \mathrm{mg} / \mathrm{mL})$ was not as remarkable compared to other studies made on the inhibition of $L$. theobromae using plant extracts. ${ }^{51,52}$ The study hypothesized that the result was attributed to the natural defense metabolites of plants which were not present in $P$. viridis because of the bivalves' low exposure to pathogenic fungi.

\section{CONCLUSION}

Both qualitative zoochemical screening and TLC analysis revealed that the crude methanolic extract of $P$. viridis comprised of the following zoochemicals: alkaloids, saponins, sterols, terpenoids, and polyphenols. All the test bacteria were susceptible to the extract, with $S$. aureus and $P$. aeruginosa being the most inhibited in terms of growth. Among the three fungi tested, $L$. theobromae was the only fungus inhibited by the extract - with MIC of $33.33 \pm 11.79$ 
$\mathrm{mg} / \mathrm{mL}$. The extract exhibited a promising MIC against $S$. aureus and $P$. aeruginosa with values of $2.60 \pm 0.63$ and $3.65 \pm 1.69 \mathrm{mg} / \mathrm{mL}$, respectively.

\section{Recommendation}

The proponents recommend evaluating zoochemicals in different locations and evaluating it further to establish a trend on the effects of the environment on their antimicrobial bioactivities. It is also suggested that the MIC per test organism should be determined and tested against the test organisms using the disk diffusion assay to further narrow the gap of the disparity of ZOIs in literature. Furthermore, better bioactivities might be achieved if zoochemicals were purified and isolated.

\section{Acknowledgment}

The authors wish to thank Asst. Prof. Marjhun A. Ricarte for the material used in TLC and his advice on the various chemical analyses done.

\section{Statement of Authorship}

All authors participated in data collection and analysis and approved the final version submitted.

\section{Author Disclosure}

All authors declared no conflict of interest.

\section{Funding Source}

This study was funded by IARRD, DOST- PCAARRD through the UPV Mussel Biotechnology Program.

\section{REFERENCES}

1. Proksch P, Ebel R, Edrada RA, Wray V, Steube K. Bioactive natural products from marine invertebrates and associated fungi. Prog Mol Subcell Biol. 2003;37:117-42. DOI:10.1007/978-3-642-55519-0_5.

2. Cimino G, Gavagnin M. Molluscs: Progress in Molecular and Subcellular Biology Subseries Marine Molecular Biochemistry. Heidelberg: Springer- Verlag Berlin; 2006. p. 387.

3. Nicholson S, Lam PK. Pollution monitoring in Southeast Asia using biomarkers in the mytilid mussel Perna viridis (Mytilidae: Bivalvia). Environ Int. 2005 Jan;31(1):121-132. DOI: 10.1016/j. envint.2004.05.007.

4. Sreejamole KL, Radhakrishnan CK. Preliminary Qualitative Chemical Evaluation of the Extracts from Mussel Perna viridis. Int J Pharm Sci Rev Res. 2010;5:38-42.

5. Shanmugam S, Shankar K, Ramachandiran S, Naidu K, Kalimuthu $\mathrm{K}$, Muthuvel A. In vitro studies and characterization of tissue protein from green mussel, Perna viridis (Linnaeus, 1758) for antioxidant and antibacterial potential. Int J Pept Res Ther 26, 159-69, 2020. https://doi.org/10.1007/s10989-019-09825-3.

6. Chandran B, Rameshkumar G, Ravichandran S. Antimicrobial Activity from the Gill Extraction of Perna viridis (Linnaeus, 1758). GJBBR. 2009;4:88-92.

7. Arjunan M, Prakash L, Salamah AA. HPTLC Separation of antibacterial compounds from Perna viridis and Portunus sanguinolentus and its activity tested against common bacterial pathogens. Adv Biotech. 2010; 9(9): 24-8.

8. Demain AL, Fang A. The natural functions of secondary metabolites. In History of modern biotechnology I. 2000; 1-39. DOI: 10.1007/ 3-540-44964-7_1.
9. Ebada SS, Lin W, Proksch P. Bioactive sesterterpenes and isoterpenes from marine sponges: occurrence and pharmacological significance. Mar Drugs. 2010 Feb 23;8(2):313-46. doi: 10.3390/md8020313.

10. Dominguez XA. Metodos de Investigacion Fitoquimica. Mexico: Editorial Limusa; 1973.p. 281.

11. Markham KR. Techniques of flavonoid Identification. Biological Techniques Series. New York: Academic; 1982. p. 113.

12. Farnsworth NR. Biological and phytochemical screening of plants. J. Pharm. Sci. 1966;55(3): 225-76.

13. Liebermann NC. Uber das Oxychinoterpen. Chem. Ber. 1885;18:1803.

14. Salkowski EI. The Reaction of cholesterol with sulfuric acid. Arch. Physiol. 1872;6:207.

15. Keller CC. Keller's Reagent. Arch Pharm BerDtsch Pharm Ges. 1895;5:277.

16. Sharma V, Singh R, Sharma S. Comparative Phytochemical Investigation with TLC Profiling of Indigofera tinctoria Linn. Extracts. PNAS. 2006;39:337-341.

17. Jamuna S, Paulsamy S. Thin-Layer chromatographic Analysis for various secondary metabolites in the methanolic leaf and root extracts of Hypochaeris radicata L. Am J Pharm Tech Res. 2014;4(2):145-56.

18. Wagner H, Bladt, S. Plant Drug Analysis. Heidelberg: Springer Verlag Berlin; 1996. p. 369.

19. Jayashree D. Phytochemical Analysis and TLC Fingerprinting of Methanolic Extracts of Three Medicinal Plants. Int Res J Pharm 2013,4(6). 2013;4:123-6. DOI: 10.7897/2230-8407.04627.

20. Cannell, R.J.P. Natural Products Isolation. New Jersey: Humana Press Inc.; 1998. p. 473.

21. Bauer AW, Kirby WMM, Sherris JC, Turck M. Antibiotic Susceptibility testing by a standardized disk method. Am J Clin Pathol. 1966 Apr;45(4):493-6.

22. Fontonelle RO, Morais SM, Brito EH. Chemical Composition, toxicological aspects and antifungal activity of essential oil from Lippiasidoides Cham. J Antimicrob Chemother. 2007 May;59(5): 934-40. Epub 2007 Mar 21.

23. Lima-Filho JV, Cordeiro RA. In Vitro and In Vivo Antibacterial and Antifungal Screening of Natural Plant Products: Prospective Standardization of Basic Methods. New York: Springer Science Business Media; 2014. pp. 275-292. DOI: 10.1007/978-1-46148636-7_17.

24. National Committee for Clinical Laboratory Standards (NCCLS). Performance Standards for Antimicrobial Disk and Dilution Susceptibility Testing; Fourteenth Informational Supplement NCCLS documents M100- S14. 2004. Wayne, Pennsylvania, USA.

25. Clinical and Laboratory Standards Institute (CLSI). Performance Standards for Antimicrobial Susceptibility Testing. Twenty-sixth edition of Informational supplement to CLSI approved standards M02-A12, M07-A10, and M11-A8. 2016. Wayne. Pennsylvania, USA.

26. Clinical and Laboratory Standards Institute (CLSI). Method for Antifungal disk diffusion Susceptibility Testing of Nondermatophyte filamentous fungi, Approved guideline. CLSI document M51-A. 2010. Wayne. Pennsylvania, USA.

27. Joy M, Chakraborty K. An unprecedented antioxidative isopimarane norditerpenoid from bivalve clam, Paphia malabarica with anti-cyclooxygenase and lipoxygenase potential. Pharm Biol. 2017;55(1):819-24. doi: 10.1080/13880209.2017.1280061.

28. Sadjadi N. Chemical Ecology of Biocompounds in Molluscs. Intech Open. 2018;1:231-245. DOI: 10.5772/intechopen.72741.

29. Benkendorff K, Davis AR, Rogers CN, Bremner JB. Free fatty acids and sterols in the benthic spawn of aquatic molluscs, and their associated antimicrobial properties. J Exp Mar Biol Eco. 2005;316: 29-44. doi.org/10.1016/j.jembe.2004.10.001.

30. Abad MJ, Bedoya LM, Bermejo P. Marine compounds and their antimicrobial activities. Science against microbial pathogens: communicating current research and technological advances. A Mendez Vilas. 2011;1:1293-306.

31. Sreejamole KL, Radhakrishnan CK, Padikkala J. Anti-inflammatory activities of aqueous/ethanol and methanol extracts of Perna viridis Linn. in mice. Inflammopharmacology. 2011 Feb 27; 19(2011): 335-341. doi: 10.1007/s10787-010-0075-z. 
32. Badhani B, Sharma N, Kakkar R. Gallic acid: a versatile antioxidant with promising therapeutic and industrial applications. RSC Advances. 2015;5:27540-27557.

33. Stead P, Hiscox S, Robinson PS. Eryloside F, a novel penasterol disaccharide possessing potent thrombin receptor antagonist activity. Bioorganic \& Medicinal Chemistry Letters. 2000 Apr;10(7):661-4.

34. Omran NEE, Allam NG. Screening of microbial contamination and antimicrobial activity of sea cucumber Holothuria polii. Toxicol. Ind. Health. 2012;29:944-54.

35. Scholz B, Liebezeit G. Chemical screening for bioactive substances in culture media of microalgae and cyanobacteria from marine and brackish water habitats: first results. Pharm. Biol. 2006;44:544-9.

36. Prabakaran G, Moovendhan M, Arumugam A, Matharasi A, Dineshkumar R, Sampathkumar P. Quantitative Analysis of phytochemical profile in marine microalgae Chlorella vulgaris. International Journal of Pharmacy and Biological Sciences. 2018;8(2):562-5.

37. Khairy HM. Allelopathic effects of Skeletonema costatum (Bacillariophyta) exometabolites on the growth of Nannochloropsis oculata and Tetraselmischuii (Chlorophyta). Egyptian J. Exp. Biol. 2010;6:79-85.

38. Ita Widowati et al 2017 IOP Conf. Ser.: Earth Environ. Sci. 55012067.

39. Madhu VN, Sivaperumal P, Kamala K, Ambekar AA, Kulkarni BG. Antibacterial and Antioxidant activities of the tissue extract of Pernaviridis Linnaeus, 1758 (Mollusca: Bivalvia) from Versova Coast, Mumbai. Int J Pharm Pharm Sci. 2014;6(2):704-7.

40. Arai M, Sobou M, Vilcheze C, Baughn A, Hashizume H, Pruksakorn, $\mathrm{P}$, et al. Halicyclamine A, marine spongean alkaloid as a lead for anti-tuberculosis agent. Bioorg Med Chem. 2008 Jul 15;16(14):6732-6. doi: 10.1016/j.bmc.2008.05.061.

41. Derengowski LS, De-Souza-Silva C, Braz SV, Mello-de-Sousa TM, Bao SN, Kyaw CM, et al. Antimicrobial effect of farnesol, a Candida albicans quorum sensing molecule, on Paracoccidioides brasiliensis growth and morphogenesis. Ann Clin Microbiol Antimicrob. 2009 Apr 29;8:13. doi: 10.1186/1476-0711-8-13.

42. Kanafani ZA, Perfect JR. Resistance to antifungal agents: Mechanisms and Clinical Impact. Clin Infect Dis. 2008 Jan 1;46(1):120-8. doi: $10.1086 / 524071$.
43. Macedo D, Leonardelli F, Dudiuk C, Theill L, Cabeza MS, Gamarra S, et al. Molecular confirmation of the linkage between the Rhizopusoryzae CYP51A Gene coding region and its intrinsic Voriconazole and Fluconazole Resistance. Antimicrob Agents Chemother. 2018 Jul 27;62(8). pii: e00224-18. doi: 10.1128/ AAC.00224-18. Print 2018 Aug.

44. Kim S, Park S, Kim H, Kim D, Lee S, Kim HT, et al. Isolation and characterization of the Colletotrichum acutatum ABC Transporter CaABC1. Plant Pathol. J. 2014;30:375-83.

45. Balkis MM, Leidich SD, Mukherjee PK, Ghannoum MA. Mechanisms of fungal resistance: an overview. Drugs. 2002;62: 1025-40. DOI:10.2165/00003495-200262070-00004.

46. Derengowski LS, De-Souza-Silva C, Braz SV, Mello-de-Sousa TM, Bao SN, Kyaw CM, Silva-Pereira I. Antimicrobial effect of farnesol, a Candida albicans quorum sensing molecule, on Paracoccidioides brasiliensis growth and morphogenesis. Ann Clin Microbiol Antimicrob. 2009 Apr 29;8:13. doi: 10.1186/1476-0711-8-13.

47. Hornby JM, Jensen EC, Lisec ED, Tasto JJ, Jahnke B, Shoemaker R, Dussault P, Nickerson KW. Quorums sensing in the dimorphic fungus Candida albicans is mediated by farnesol. Appl Environ Microbiol. 2001 Jul; 67(7): 2982- 92.

48. Inoue Y, Hada T, Shiraishi A, Hirose K, Hamashima H, Kobayashi S. 2005. Biphasic Effects of Geranylgeraniol, Terpenone, and Phytol on the growth of Staphylococcus aureus. Antimicrob Agents Chemother. 2005 May; 49(5): 1770-4. doi: 10.1128/AAC.49.5.1770-1774.2005.

49. Melander, R. J., Liu, H. B., Stephens, M. D., Bewley, C. A., \&Melander, C. Marine sponge alkaloids as a source of anti-bacterial adjuvants. Bioorg Med Chem Lett. 2016 Dec 15; 26(24): 5863-6. doi: 10.1016/ j.bmcl.2016.11.018.

50. Borquaye LS, Darko G, Oklu N, Anson-Yevu C, Ababio A. Antimicrobial and antioxidant activities of ethyl acetate and methanol extracts of Littorina littorea and Galatea paradoxa. Cogent Chem. 2016;2:1161865.

51. Oliveira AK, Rizzi ES, Pereira KC, Bono JA, Pinas JC, Matias, R. Phytochemical analysis and fungicide potential of Pouteria ramiflora against Lasiodiplodia theobromae. Hortic. Bras. [online]. 2017; 35(4);564-570. ISSN 0102-0536. https://doi.org/10.1590/ s0102-053620170414.

52. Lakshmi BS, Naidu KC. Antimicrobial activity of Piper betle (L.) leaf extracts against pathogens of Cereal crops. BioMedRx. 2013;1:712-4. 